\title{
Chronic toxicity of dietary copper to Daphnia magna.
}

This is a post-print of a paper published in Aquatic Toxicology (Elsevier, Amsterdam, The Netherlands). The contents are identical to those in the published version.

Full bibliographic citation (please cite as follows):

De Schamphelaere KAC, Forrez I, Dierckens K, Sorgeloos P, Janssen CR. Chronic toxicity of dietary copper to Daphnia magna. Aquatic Toxciology 81: 409-418.

Link to published journal version (via digital object identifier):

http://dx.doi.org/10.1016/j.aquatox.2007.01.002 


\section{Chronic toxicity of dietary copper to Daphnia magna}

2

3 De Schamphelaere, K.A.C. ${ }^{1 *}$; Forrez, I. ${ }^{1}$; Dierckens, K. ${ }^{2}$; Sorgeloos, P. ${ }^{2}$; Janssen, C.R. ${ }^{1}$

4

$5{ }^{1}$ Laboratory of Environmental Toxicology and Aquatic Ecology, Faculty of Bioscience

6 Engineering, Department of Applied Ecology and Environmental Biology, Ghent University

7 (UGent), Jozef Plateaustraat 22, B-9000 Gent, Belgium

8

$9{ }^{2}$ Laboratory of Aquaculture \& Artemia Reference Center, Faculty of Bioscience Engineering,

10 Department of Animal Production, Ghent University (UGent), Rozier 44, B-9000 Gent,

11 Belgium

12

13

14

15

$16 *$ Corresponding author

17 Dr. Karel De Schamphelaere

18 Laboratory of Environmental Toxicology and Aquatic Ecology

19 Jozef Plateaustraat 22

20 B-9000 Gent, Belgium

21 Tel. +3292643764

$22 \quad$ Fax. +3292643766

23 E-mail: Karel.Deschamphelaere@Ugent.be 


\section{$1 \quad$ Abstract}

2 There is a growing concern that dietborne metal toxicity might be important in aquatic ecosystems. However, the science behind this matter is insufficiently developed to explicitly and accurately account for this in metals regulation or risk assessment. We investigated the effects of a chronic exposure of Daphnia magna to an elevated level of $\mathrm{Cu}(3,000 \mu \mathrm{g} \mathrm{Cu} / \mathrm{g}$ dry wt) in their diet (the green alga Pseudokirchneriella subcapitata). Compared to daphnids fed with $P$. subcapitata containing a background of $10.6 \mu \mathrm{g} \mathrm{Cu} / \mathrm{g}$ dry wt, daphnids fed for 21 days with this $\mathrm{Cu}$-contaminated food accumulated a total copper body burden of $325 \mu \mathrm{g} \mathrm{Cu} / \mathrm{g}$ dry wt, which is about 30 -fold higher than the control body burden of $12.1 \mu \mathrm{g} / \mathrm{g}$ dry wt. The exposed daphnids experienced a 38\% reduction of growth (measured as final dry body weight), a 50\% reduction of reproduction (total number of juveniles produced per daphnid), and only produced three broods (vs. four broods by the control daphnids). Unlike most other studies, we were able to demonstrate that these effects were most likely not due to a reduced nutritional quality of the food, based on C:P ratios and fatty acid content and composition of the $\mathrm{Cu}$-contaminated algae. Life-history analysis showed that time to first brood was not affected by dietary $\mathrm{Cu}$, while the second and third broods were significantly delayed by 0.7 and 1.5 days, respectively. On the other hand, brood sizes of all three broods were significantly lower in $\mathrm{Cu}$ exposed daphnids, i.e. by $32 \%$ to $55 \%$. The variety of effects observed suggest the possible, and perhaps simultaneous, involvement of several toxicity mechanisms such as increased metabolic cost, reduced energy acquisition (potentially via inhibition of digestive enzyme activity), targeted inhibition of reproduction (potentially via inhibition of vitellogenesis), and/or direct inhibition of molting. Further research is needed to differentiate between these postulated mechanisms of dietary $\mathrm{Cu}$ toxicity and to determine whether they act separately or in concert.

25 Keywords Daphnia; copper; dietborne metal exposure; metal toxicity 


\section{Introduction}

(

There is growing evidence that dietborne metal toxicity might be important in aquatic ecosystems (Wikfors and Ukeles, 1982; Moreno-Garrido et al., 1999; Hook and Fisher, 2001a, 2001b, 2002; Clearwater et al., 2002; De Schamphelaere et al., 2004; Borgmann et al., 2005; Meyer et al., 2005). The current understanding of dietborne metal toxicity is, however, insufficiently developed and, as a consequence, the dietary exposure route is generally not considered explicitly in most existing regulations or risk assessments (Schlekat et al., 2001; Borgmann et al., 2005).

\section{Recently, several studies have been published concerning the effects of dietary metal} exposure on crustacean species. Hook and Fisher (2001a, 2002) reported the inhibition of reproduction in marine copepods fed with diatoms contaminated with $\mathrm{Mn}, \mathrm{Zn}, \mathrm{Ag}, \mathrm{Cd}$, or $\mathrm{Hg}$ and in cladocerans fed with green algae contaminated with Ag (Hook and Fisher, 2001b). The absence of more general stress responses (i.e., respiration and behavior) as well as reduced egg protein content, led these authors to hypothesize that dietary metals invoke an effect specifically targeting reproduction, potentially linked to the inhibition of processes related to vitellogenesis. Their hypothesis was supported by the fact that $\mathrm{Cd}$ had been shown to reduce vitellogenin production in blue crabs, Callinectes sapidus (Lee and Noone, 1995). More recently, De Schamphelaere et al. (2004) demonstrated a similar specific reproductive effect of dietary $\mathrm{Zn}$ (accumulated in green algae) on the cladoceran Daphnia magna, with no general stress response observed (no effects on survival, growth or feeding rate).

Earlier-reported effects of dietborne $\mathrm{Cu}$ exposure on crustaceans are less consistent. De Schamphelaere and Janssen (2004a) demonstrated a stimulation of D. magna growth and reproduction by dietary $\mathrm{Cu}$ (incorporated at internal concentrations between 680 and $1400 \mu \mathrm{g}$ 
$1 \mathrm{Cu} / \mathrm{g}$ dry wt in the alga Pseudokirchneriella subcapitata) and hypothesized that this effect

2 might be related to an enhanced digestive enzyme activity (supported by studies of Chen et

3 al., 2002; and Kirchgessner et al., 1976). On the other hand, Chang and Sibley (1993)

4 reported an inhibition of reproduction in D. magna fed with the $\mathrm{Cu}$-contaminated green alga

5 Oocystis pusilla. Unfortunately, the latter authors did not consider other organism traits such

6 as growth or feeding rates. Therefore, it is unclear whether the reproductive inhibition was a

7 targeted effect (like for dietary Zn exposure in D. magna, De Schamphelaere et al., 2004) or

8 whether it was the result of a more general stress response (e.g., reduced feeding, increased

9 metabolic costs). Although diet quality shifts due to pre-exposure of live algal food to $\mathrm{Zn}$

10 were not considered a likely explanation for inhibited reproduction in daphnids (De

11 Schamphelaere et al., 2004), one cannot exclude a priori that diet quality shifts were

12 important in the Chang and Sibley (1993) study with $\mathrm{Cu}$.

14 Based on all this, the major aim of the present study was to investigate whether an elevated level of dietary $\mathrm{Cu}$ would specifically inhibit reproduction in daphnids (as for other metals), or whether a more general stress response would be invoked (e.g., effects on survival, growth and/or feeding rate). This was investigated by feeding D. magna in a 21-day chronic bioassay with the alga $P$. subcapitata which had been contaminated with a high internal $\mathrm{Cu}$ concentration. In parallel with the bioassay we also quantified diet quality in control and $\mathrm{Cu}$ contaminated algal food as defined by the C:P ratio and the fatty acid composition. A level of

$21 \mathrm{Cu}$ contamination of the food was selected that was higher than the one that previously

22 resulted in stimulation of growth and reproduction in D. magna (De Schamphelaere and Janssen, 2004a) and that had been shown in a preliminary experiment to inhibit growth and reproduction in D. magna (unpublished data). The main focus of this study was not so much on assessing the effects of a realistically contaminated $\mathrm{Cu}$-diet but rather on getting basic 
1 information about possible physiological mechanisms of toxicity of dietborne $\mathrm{Cu}$ in a model

2 crustacean.

3

\section{Materials and methods}

\section{Experimental design}

7 The green alga $P$. subcapitata was cultured in a control medium and medium containing an elevated $\mathrm{Cu}$ concentration for three days. The algae were harvested and their nutritional value (in terms of their C:P ratio and essential fatty acid content) and internal copper burden were determined. The algae were fed to D. magna in chronic bioassays where survival, feeding rate, growth and reproduction was recorded for 21 days.

Test media

Exposures of $P$. subcapitata and D. magna were performed in a reconstituted test medium containing natural dissolved organic carbon collected by reverse osmosis from the Ankeveensche Plassen, The Netherlands (a freshwater ditch belonging to a system of connect lakes; see De Schamphelaere et al., 2003 for a detailed description). The test media contained $10 \mathrm{mg}$ dissolved organic carbon $\mathrm{L}^{-1}, 2.0 \mathrm{mM} \mathrm{Ca}, 0.50 \mathrm{mM} \mathrm{Mg}, 5.2 \mathrm{mM} \mathrm{Na}, 0.078 \mathrm{mM} \mathrm{K}$, $0.50 \mathrm{mM} \mathrm{SO}_{4}$, and $4.1 \mathrm{mM} \mathrm{Cl}$. 3-N morpholino propane sulfonic acid (MOPS, SigmaAldrich, Steinheim, Germany) was added at a concentration of $3.6 \mathrm{mM}$ as a $\mathrm{pH}$ buffer to maintain $\mathrm{pH}$ around 8 . The alga test medium, but not the Daphnia test medium, contained additional macronutrients $\left(\mathrm{NH}_{4}, \mathrm{PO}_{4}\right)$ and micronutrients (Fe, $\mathrm{B}, \mathrm{Mn}, \mathrm{Zn}, \mathrm{Co}$, and $\mathrm{Mo}$ ) at the concentrations described in OECD test guideline 201 (OECD, 1984). The strong metalchelator ethylene-diamine-tetra-acetate (EDTA) was omitted from the solution. 


\section{$1 \quad$ Algae exposure}

2 Pseudokirchneriella subcapitata (CCAP 278/4) originated from the Culture Collection of

3 Algae and Protozoa (currently hosted at the Scottish Association for Marine Science, Argyll,

4 Scotland) and is continuously maintained in our laboratory according to procedures described

5 elsewhere (De Schamphelaere et al., 2005). Log-phase algae were used to initiate the

6 exposures. Algae were cultured for three days in a control test solution (no added $\mathrm{Cu}$ ) and a

7 solution with $500 \mu \mathrm{g} / \mathrm{L}$ added $\mathrm{Cu}$ (added as $\mathrm{CuCl}_{2}$ ). Ten liters of test medium were prepared,

8 spiked with copper and transferred into a polyethylene bag. The spiked media were

9 equilibrated for 48 hours at $20^{\circ} \mathrm{C}$ and then each bag was inoculated with $5 \cdot 10^{5}$ cells $\mathrm{ml}^{-1}$.

10 Exposures were carried out under continuous illumination $\left(240 \mu \mathrm{mol}\right.$ photons $\left.\mathrm{m}^{-2} \mathrm{~s}^{-1}\right)$ and

11 continuous aeration at 20 to $21^{\circ} \mathrm{C}$. Initial and final biomass (dry weight) were determined in

12 triplicate according to De Schamphelaere et al. (2004) and the biomass growth rate was

13 determined according to OECD guideline 201 (1984). After 72 hours of exposure, the algae

14 were harvested by centrifugation using a continuous-flow centrifuge with a volume of 300

$15 \mathrm{~mL}$ at a flow rate of $2.5 \mathrm{~mL} \mathrm{~s}^{-1}$ and a g-force of $1,000 \mathrm{~g}$ (IEC Chemical centrifuge,

16 International Equipment Company, USA). The supernatant was pipetted off and the resulting

17 pellets were stored in darkness at $4^{\circ} \mathrm{C}$ in $300 \mathrm{~mL}$ of supernatant. Hence, the algae were stored

18 in the same solution chemistry as the one they had been exposed in. This minimizes changes

19 in internal copper burdens of the algae during the storage of the concentrated cell suspensions

20 (De Schamphelaere and Janssen, 2004a).

\section{Algal characteristics}

23 Dry weight, internal copper content, molar C:P ratio, and fatty acid contents of the algae from

24 the stored suspensions were determined at the start and at the end of the chronic D. magna

25 bioassay. Dry weight determination and sample preparation for internal and external copper 
1 burdens were carried out following procedures described in De Schamphelaere and Janssen

2 (2004a). External copper is operationally defined as the copper that is desorbed from the algal

3 surface by a 20 minute wash in a solution of a $5 \mathrm{mM}$ ethylene-diamine-tetra-acetic acid

4 solution. Internal copper is the copper remaining inside the cells after this treatment (De

5 Schamphelaere and Janssen, 2004a). Copper analyses were performed with graphite furnace

6 atomic absorption spectrophotometry (SpectrAA800 with Zeeman background correction,

7 Varian, Mulgrave, Australia). A reference plankton sample (BCR-414, Institute for Reference

8 Materials and Measurements, Geel, Belgium) was analyzed using the same method. Measured

9 copper levels were within $10 \%$ of the certified value. Carbon content was determined as

10 explained in De Schamphelaere and Janssen (2004a). Total phosphorus content was

11 determined by nitric acid - sulfuric acid digestion and colorimetric phosphate determination,

12 according to APHA method 4500-P (Clesceri et al., 1998). Molar C:P ratios were calculated

13 from the carbon and phosphorus contents.

14 Fatty acid composition was determined by gas chromatography. Fatty acid methyl esters

15 (FAME) were prepared via a modified procedure of Lepage and Roy (1984). This method

16 implies a direct acid catalysed transesterification without prior extraction of total fat on 10 to

$17150 \mathrm{mg}$ dry weight of sample. An internal standard of eicosadienoic acid, 20:2(n-6), was

18 added prior to the reaction. FAME were extracted with hexane and, after evaporation of the

19 solvent, prepared for injection in the chromatograph by dissolution in iso-octane $(2 \mathrm{mg} / \mathrm{ml})$.

20 Quantitative determination was done by a Chrompack CP9001 gas-chromatograph equipped

21 with an autosampler and a temperature programmable on-column injector. Injections $(0.2 \mu 1)$

22 were performed on-column into a polar 50 m capillary column, BPX70 (SGE, Australia), with

23 a diameter of $0.32 \mathrm{~mm}$ and a layer thickness of $0.25 \mu \mathrm{m}$ connected to a $2.5 \mathrm{~m}$ methyl

24 deactivated pre-column. The carrier gas was $\mathrm{H}_{2}$, at a pressure of $100 \mathrm{kPa}$ and the detection

25 mode was flame ionization detection. The oven was programmed to rise from the initial 
1 temperature of $85^{\circ} \mathrm{C}$ to $150^{\circ} \mathrm{C}$ at a rate of $30^{\circ} \mathrm{C} / \mathrm{min}$, from $150^{\circ} \mathrm{C}$ to $152^{\circ} \mathrm{C}$ at $0.1^{\circ} \mathrm{C} / \mathrm{min}$, from

$2152^{\circ} \mathrm{C}$ to $172^{\circ} \mathrm{C}$ at $0.65^{\circ} \mathrm{C} / \mathrm{min}$, from $172^{\circ} \mathrm{C}$ to $187^{\circ} \mathrm{C}$ at $25^{\circ} \mathrm{C} / \mathrm{min}$ and remained at $187^{\circ} \mathrm{C}$ for

$37 \mathrm{~min}$. The injector was heated from $85^{\circ} \mathrm{C}$ to $190^{\circ} \mathrm{C}$ at $5^{\circ} \mathrm{C} / \mathrm{sec}$ and remained at $190^{\circ} \mathrm{C}$ for 30

4 min. Identification was based on standard reference mixtures (Nu-Chek-Prep, Inc., U.S.A.)

5 and calculations were performed by the software program Maestro (Chrompack).

6

7 Chronic bioassays with daphnids

8 Chronic bioassays were performed according to OECD guideline No. 211 for testing of

9 chemicals (OECD, 1998). Test organisms originated from a healthy D. magna clone which

10 was cultured in the laboratory under standardized conditions in M4 medium (Elendt and Bias,

11 1991). At the start of each test, 10 juveniles ( $<24$ hours old) were transferred individually to

12 polyethylene cups containing $40 \mathrm{ml}$ of test medium (i.e., 10 replicates of one organism per concentration). Every day the daphnids were fed with 60,90 and $120 \mu \mathrm{g}$ dry wt algae during the first, second, and third week of the exposure, respectively. This corresponds to 24,36 , and $48 \mu \mathrm{g} \mathrm{C}$ per day, respectively. These daily food rations are 4 to 8 -fold lower than those recommended by the OECD test guideline and 5 times lower than those used in our earlier studies (De Schamphelaere and Janssen, 2004a, 2004b). Although it was anticipated that this would result in a total reproductive output lower than the 60 juveniles/daphnid as required by the test guideline, the lower food rations were needed to maintain the dissolved $\mathrm{Cu}$ levels in the Daphnia exposure vessels at a level low enough to avoid as much as possible toxic effects via the waterborne route (see also results section). This is because increasing the food rations increases the total amount of copper added to the test vessels and hence also increases the potential of the establishment of toxic copper concentrations in the water. The chosen food concentration was a trade-off between ensuring quantifiable reproduction and minimizing the built-up waterborne copper concentrations. Daphnids were transferred to fresh solutions on 
1 day $2,5,7,9,12,14,16$ and 19 of the exposure. Samples were taken from old test solutions

2 to determine possible leaching of copper from the contaminated algal food. The number of

3 algal cells remaining in the old test solutions was determined to calculate per capita algal

4 ingestion rates of the daphnids, i.e. the amount of algae ingested per day and per individual

5 daphnid (De Schamphelaere and Janssen, 2004a). Every day, parent mortality and the number

6 of juveniles were noted in each replicate. At the end of the 21 day exposure period, mortality

7 and the number juveniles was noted for the last time and parent daphnids were collected for

8 dry weight and copper body burden determination as explained in De Schamphelaere and

9 Janssen (2004a). Daphnids were fed for 8 hours with the control algae prior to copper body

10 burden determination. This approach is recommended to ensure that ingested $\mathrm{Cu}$ is efficiently

11 removed from the gut lumen (Gillis et al., 2005).

12

\section{Chemical analyses}

14 Copper concentrations in algal and daphnid exposure solutions were determined using a

15 graphite furnace atomic absorption spectrophotometer (for $\mathrm{Cu}<20 \mu \mathrm{g} \mathrm{L}^{-1}$, SpectrAA800 with

16 Zeeman background correction, Varian, Mulgrave, Australia). Dissolved copper (filtration

17 through $0.45 \mu \mathrm{m}$, Gelman Sciences, Ann Arbor, Michigan, U.S.) was measured daily in the

18 algal exposure solutions and just prior to each test solution renewal in the D. magna tests.

\section{Data treatment and statistics}

21 All data are reported as mean \pm standard deviation, unless noted otherwise. Non-parametric

22 statistics, i.e. Mann-Whitney U, Spearman Rank Correlation and Wilcoxon Matched Pairs, 23 were used in all instances and were carried out using Statistica 6.0 software (Statsoft, Tulsa,

24 OK, U.S.A.) 


\section{Results}

2 Results of the algae exposures and the analyses of algal composition are summarized in Table

3 1. P. subcapitata were exposed for 72 hours to measured concentrations of $1.9 \mu \mathrm{g} \mathrm{Cu} / \mathrm{L}$

4 (control) and $494 \mu \mathrm{g} \mathrm{Cu} / \mathrm{L}$ (Table 1). Compared to the control, the growth rate of the algae

5 was reduced by $59 \%$ when exposed to $494 \mu \mathrm{g} \mathrm{Cu} / \mathrm{L}$ (Table 1). Internal $\mathrm{Cu}$ concentrations in

6 the algae during the D. magna bioassays were between 8.9 and $12.3 \mu \mathrm{g} \mathrm{Cu} / \mathrm{g}$ dry wt (control)

7 and between 2,720 and 3,290 $\mu \mathrm{g} \mathrm{Cu} / \mathrm{g}$ dry wt (494 $\mu \mathrm{g} \mathrm{Cu} / \mathrm{L}$ treatment). The molar C:P ratio

8 was $12 \%$ lower in the $\mathrm{Cu}$-treated (241) than in the control cells (274). Total fatty acids

9 comprised $6.6 \%$ of the dry wt in control cells and $9.4 \%$ in Cu-treated cells. The most

10 abundant fatty acids present in the control algae were palmitic (23\% of all fatty acids on a

11 weight basis), oleic (29\%), linoleic (7.4\%), linolenic (16\%) and parinaric (or stearidonic) acid

12 (4.4\%), while the essential fatty acids eicosapentaenoic acid (EPA, 0.9\%) and

13 docosahexaenoic (DHA, <0.03\%) were only present in traces or were undetectable,

14 respectively. Copper-treated cells contained a similar concentration of EPA $(4.5 \mathrm{nmol} / \mathrm{g} \mathrm{C})$ as

15 the control cells $(4.7 \mathrm{nmol} / \mathrm{g} \mathrm{C})$, but higher concentrations of palmitic (25\% more than

16 control) and oleic acid (170\% more than control), and lower concentrations of linoleic (52\%

17 less) and linolenic acid (37\% less). Total $\omega 3$-PUFA concentrations were $125.7 \mathrm{nmol} / \mathrm{g} \mathrm{C}$ in

18 control cells and $89.5 \mathrm{nmol} / \mathrm{g} \mathrm{C}$ in Cu-treated cells, which is $29 \%$ less than in controls.

20 Results of the Daphnia magna tests are summarized in Table 2. The mean dissolved $\mathrm{Cu}$

21 concentration measured in old test solutions of the treatment fed with $\mathrm{Cu}$ contaminated algae 22 was $36.5 \mu \mathrm{g} / \mathrm{L}$ (Table 2).

24 All daphnids in the control treatment and in the $\mathrm{Cu}$-contaminated series survived the 21-day 25 exposure. While 21-day old daphnids fed the control food had a body burden of $12.1 \mu \mathrm{g} \mathrm{Cu} / \mathrm{g}$ 
1 dry wt, daphnids fed $\mathrm{Cu}$-contaminated algae had a significantly (MWU, $\mathrm{p}<0.001$ ) higher $\mathrm{Cu}-$

2 burden at $325 \mu \mathrm{g} \mathrm{Cu} / \mathrm{g}$ dry wt (Table 2). Daphnids fed $\mathrm{Cu}$-contaminated algae exhibited a

3 significant (MWU, p<0.001) 50\% reduction of total reproduction and a significant (MWU,

$4 \mathrm{p}<0.01$ ) $38 \%$ reduction of growth over the 21-day period (Table 2). Although the time to first

5 brood was not affected (MWU, $\mathrm{p}>0.05$ ), the release of the second brood was significantly

6 delayed by 0.7 days (MWU, p<0.05), and the release of the third brood by 1.5 days (MWU,

$7 \mathrm{p}<0.001)$. Only $30 \%$ of the control daphnids were able to produce a $4^{\text {th }}$ brood while none of

8 the daphnids exposed to $\mathrm{Cu}$-contaminated food were able to do so within the 21-day exposure

9 period. On the other hand, brood sizes of all three broods were significantly reduced by

10 dietary $\mathrm{Cu}(\mathrm{MWU}, p<0.01)$. The first, second, and third brood sizes in the dietary $\mathrm{Cu}$

11 treatment were decreased by $32 \%, 35 \%$ and $55 \%$, respectively.

12

13 Per capita algal ingestion rates of $\mathrm{Cu}$-exposed daphnids were significantly lower than in the

controls (Wilcoxon Matched Pairs test, $\mathrm{p}<0.02, \mathrm{~N}=7$ ) (Figure 1). The inhibition increases with

time (Spearman Rank Correlation, $r=-0.86, p=0.01, N=7$ ), e.g., between $85 \%$ and $95 \%$

inhibition of control ingestion rates between day 5 and 12 of the exposure and between $62 \%$

and $70 \%$ between day 12 and 21 . The inhibition is mainly due to the fact that ingestion rates

of the control daphnids increased significantly with time (Spearman Rank Correlation, $\mathrm{r}=0.86$,

$\mathrm{p}=0.01, \mathrm{~N}=7$ ), while they did not increase in the $\mathrm{Cu}$-treated daphnids (Spearman Rank

Correlation, $\mathrm{r}=0.11, \mathrm{p}=0.82, \mathrm{~N}=7$ ) (Figure 1).

\section{Discussion}

Before interpreting the outcome of the D. magna bioassays in terms of dietary metal toxicity, 
1 occurrence of an average $\mathrm{Cu}$ concentration of $36.5 \mu \mathrm{g} \mathrm{Cu} / \mathrm{L}$ in solution during the dietary

2 exposure. This has in the first place relevance for the estimation of the true dietary copper

3 dose to which the daphnids have been subjected. Indeed, one could easily argue that too much

4 internal $\mathrm{Cu}$ leached from the algae to be sure that the daphnids have actually been exposed to

5 dietary $\mathrm{Cu}$. A mass balance calculation was therefore performed to determine the relative

6 importance of the different sources of the waterborne $\mathrm{Cu}$ in the test vessels and also to

7 estimate this true dietary dose. This calculation was based on known additions of $\mathrm{Cu}$ to the

8 test vessels and measurements of dissolved $\mathrm{Cu}$ at every test medium renewal (every two or

9 three days). An exemplary calculation is presented below for exposure period between 7 and

109 days. At day 7 a dissolved $\mathrm{Cu}$ concentration of $30.6 \mu \mathrm{g} / \mathrm{L}$ was measured, representing a

11 mass of $1,224 \mathrm{ng}$ of $\mathrm{Cu}$ in the test vessel $(30.6 \mu \mathrm{g} / \mathrm{L} \times 0.04 \mathrm{~L}$ of test volume). Four important

12 sources of this amount of copper need to be considered: (1) background $\mathrm{Cu}(2.3 \mu \mathrm{g} / \mathrm{L}$ x $0.04 \mathrm{~L}$

$13=92 \mathrm{ng} \mathrm{Cu}$ ), (2) dissolved $\mathrm{Cu}$ that was directly transferred with every feeding event from the

14 dissolved phase of the concentrated algal food suspension to the test solution $(437 \mu \mathrm{g} / \mathrm{L}$ in

15 algal suspension $\mathrm{x} 2$ feedings of $200 \mu \mathrm{L}$ of algal suspension $=172 \mathrm{ng} \mathrm{Cu}$ ), (3) $\mathrm{Cu}$ that is

16 rapidly desorbed from external binding sites on the algal surfaces when transferred into the

17 daphnids' test vessels ( 2 feedings of $90 \mu \mathrm{g}$ dry wt x $3554 \mu \mathrm{g} \mathrm{Cu} / \mathrm{g}$ dry wt external $\mathrm{Cu}=640$

$18 \mathrm{ng} \mathrm{Cu}$ ), and (4) $\mathrm{Cu}$ that is leached from the internal compartments of the algae. The latter

source was quantified by subtracting the three other sources from the total amount present, i.e.

$320 \mathrm{ng} \mathrm{Cu}$ (1224-92-640-172). Now, between day 7 and day 9, a total amount of $540 \mathrm{ng}$ of

21 internal $\mathrm{Cu}$ was added ( 2 feedings of $90 \mu \mathrm{g}$ dry wt x $3000 \mu \mathrm{g} \mathrm{Cu} / \mathrm{g}$ dry wt). Hence, during this

22 exposure period $31 \%$ of the $\mathrm{Cu}$ was retained, while $59 \%$ was leached. The same mass balance

23 calculation was repeated for each exposure period in-between two test media renewals. This

24 resulted in an average retention of internal $\mathrm{Cu}$ in the algae of $38 \%$ and an average leaching

25 into the water of $62 \%$. This means that internal $\mathrm{Cu}$ burdens of the contaminated algae fed to 
1 the daphnids were between $3,000 \mu \mathrm{g} / \mathrm{g}$ dry wt (immediately after each feeding event) and

$21160 \mu \mathrm{g} / \mathrm{g}$ dry wt (38\% of 3,000). Multiplication of this internal $\mathrm{Cu}$ range with daily food

3 ingestion rates (Figure 1), resulted in ingestion rates of $\mathrm{Cu}$ between 39 and $143 \mathrm{ng} \mathrm{Cu}$ per

4 daphnid per day over the entire exposure period. This is 50 to 360 -fold higher than the control

5 daphnids, which ingested only between 0.4 and $0.8 \mathrm{ng} \mathrm{Cu}$ per daphnid per day. As a result,

6 daphnids exposed to dietary $\mathrm{Cu}$ had body burdens of $325 \mu \mathrm{g} \mathrm{Cu} / \mathrm{g}$ dry wt, which is 30 -fold

7 higher than the control body burden of $12.1 \mu \mathrm{g} \mathrm{Cu} / \mathrm{g}$ dry wt. It is unlikely that this increased

8 accumulation is the result of the waterborne concentration of $36.5 \mu \mathrm{g} / \mathrm{L}$. Indeed, in a previous

9 study, daphnids exposed for 21 days to a waterborne concentration of $35 \mu \mathrm{g} \mathrm{Cu} / \mathrm{L}$ resulted in

10 a body burden of only $31 \mu \mathrm{g} \mathrm{Cu} / \mathrm{g}$ (De Schamphelaere and Janssen, 2004a). Moreover, the test

11 medium used in the latter study was characterized by a higher copper bioavailability since

12 DOC and hardness were similar while the $\mathrm{pH}$ of 6.8 was lower than the $\mathrm{pH}$ of 8 used in the

13 present study (lower $\mathrm{pH}$ is higher bioavailability, De Schamphelaere and Janssen, 2004b).

14 Hence, at $36.5 \mu \mathrm{g} \mathrm{Cu} / \mathrm{L}$ and $\mathrm{pH} 8$ - the conditions of the present dietary toxicity study - the

15 body burden in the daphnids originating from waterborne $\mathrm{Cu}$ would be expected to be even

16 lower than $31 \mu \mathrm{g} \mathrm{Cu} / \mathrm{g}$, which is 10 -fold lower than the measured body burden. Thus daphnids

17 exposed to dietary $\mathrm{Cu}$ in the present study accumulated at least 10-fold more $\mathrm{Cu}(325 \mu \mathrm{g}$

$18 \mathrm{Cu} / \mathrm{g})$ than the amount that would be expected from waterborne contribution alone $(<31 \mu \mathrm{g}$

$19 \mathrm{Cu} / \mathrm{g})$. Hence, the above calculations and comparison clearly indicate that dietary $\mathrm{Cu}$ in the

20 present study was ingested by the daphnids as well as assimilated into the tissues.

22 Although the presence of $36.5 \mu \mathrm{g}$ dissolved $\mathrm{Cu} / \mathrm{L}$ is clearly no indication of the absence of 23 dietary $\mathrm{Cu}$ exposure, it is still important to discuss its potential contribution to the toxic effect 24 observed. The experiment was specifically designed to minimize the bioavailability of copper 25 by performing the test in a test solution with $10 \mathrm{mg} \mathrm{DOC} / \mathrm{L}$ and a $\mathrm{pH}$ of 8 . In waterborne-only 
1 exposure using the same test water, we have previously determined a 21-day no observed

2 effect concentration (NOEC) for D. magna reproduction of $120 \mu \mathrm{g} \mathrm{Cu} / \mathrm{L}$ and a $50 \%$ inhibitive

3 concentration for reproduction (EC50) of $167 \mu \mathrm{g} \mathrm{Cu} / \mathrm{L}$ (De Schamphelaere and Janssen,

4 2004b). In our present exposure to dietary $\mathrm{Cu}$, we observed 50\% inhibition of reproduction at

5 an average dissolved $\mathrm{Cu}$ concentration of $36.5 \mu \mathrm{g} \mathrm{Cu} / \mathrm{L}$ (Table 2), which is about 5 times

6 lower than the waterborne EC50 and 3 times lower than the NOEC. Additionally, D. magna

7 exposed to $35 \mu \mathrm{g}$ waterborne $\mathrm{Cu} / \mathrm{L}$ - under conditions of slightly higher bioavailability ( $\mathrm{pH}$

86.8 vs. $\mathrm{pH}$ 8.0, see also above) - and fed with P. subcapitata contaminated with much less $\mathrm{Cu}$,

9 i.e. $330 \mu \mathrm{g} \mathrm{Cu} / \mathrm{g}$ dry wt, exhibited a slightly stimulated reproduction, rather than an inhibition

10 (De Schamphelaere and Janssen, 2004a). Obviously, it could be argued that a fair comparison

11 between these earlier studies and the present study is not possible, since the 5-fold lower food

12 concentration used in the exposures of the present study might have increased the sensitivity

13 of the daphnids to waterborne copper. However, a recent study with D. magna at our

14 laboratory (Gevaert, 2004) - in a similar test water except lower DOC (pH 7.8, $\mathrm{CaCl}_{2} 1.44$ $\mathrm{mM}, \mathrm{MgSO}_{4} 0.36 \mathrm{mM}, \mathrm{NaHCO}_{3} 0.75 \mathrm{mM}, \mathrm{KCl} 0.075 \mathrm{mM}$, DOC $4 \mathrm{mg} / \mathrm{L}=2.5$-fold lower

16 than in the present study) - yielded the same $21 \mathrm{~d}-\mathrm{NOEC}$ for reproduction of $55 \mu \mathrm{g}$ dissolved

$17 \mathrm{Cu} / \mathrm{L}$ at both normal (same as in De Schamphelaere and Janssen, 2004a, 2004b) and 5-fold reduced food concentration (same as in present study) and not-significantly-different 21dEC50's of $84 \mu \mathrm{g} / \mathrm{L}$ and $76 \mu \mathrm{g} / \mathrm{L}$ at normal and reduced food concentration, respectively. This clearly shows that a five-fold reduction of food concentration does not affect chronic toxicity

21 of waterborne $\mathrm{Cu}$ to D. magna. Also, despite the 2.5-fold lower DOC concentration used by

22 Gevaert (2004) (=2.5-fold higher bioavailability), the waterborne concentration of $76 \mu \mathrm{g} \mathrm{Cu} / \mathrm{L}$ that causes $50 \%$ reduction of reproduction at the low food concentration (same as used in the present study), is still two-fold higher than the waterborne concentration of $36.5 \mu \mathrm{g}$ waterborne $\mathrm{Cu} / \mathrm{L}$ in the present exposure to dietary copper that also reduced reproduction by 
$150 \%$. The combination of all these arguments makes it likely that the adverse effects on $D$.

2 magna, observed in the present study, were mainly due to the ingestion and/or assimilation of

$3 \mathrm{Cu}$-contaminated food and not to the dissolved $\mathrm{Cu}$ concentration present in the water.

A second potential confounding factor is that metal-contaminated food may have had a reduced nutritional quality (Meyer et al., 2005; Clearwater et al., 2002). Thus, the observed effects might be an indirect result of food quality rather than a direct toxicological impact of ingested metal (Clearwater et al., 2002; Meyer et al., 2005). According to several authors, the key factors governing nutritional food quality to D. magna and other cladocerans are the C:P ratio and the essential fatty acid content and composition of the food (Sundbom and Vrede, 1997; Park et al., 2002). Exposure to copper increased the oleic acid and palmitic acid content of algae and reduced linoleic and linolenic acid (Table 1). McLarnon Riches et al. (1998) found a similar trend for oleic acid and linoleic acid, but not for palmitic or linolenic acid. We did not observe any effects on stearidonic acid and eicosapentaenoic acid (EPA). EPA is selectively stored in eggs of D. magna and reproduction is therefore the major drain of EPA from the females (Becker and Boersma, 2005). Since EPA levels in both control and Cucontaminated food were very similar, the observed differences in reproduction cannot be related to EPA requirements of D. magna. Linolenic acid, which can be converted by daphnids into EPA (von Elert, 2002) was clearly lower in $\mathrm{Cu}$-contaminated algae than in control algae, but since the conversion rate is low (von Elert, 2002) it is unlikely that the difference in linolenic acid could explain the marked reduction in reproduction that we observed. Additionally, EPA and linolenic acid are both known to accelerate maturation in daphnids, as indicated by a reduced time to first brood in Daphnia galeata (Sundbom and Vrede, 1997). Although linolenic acid was clearly lower in $\mathrm{Cu}$-contaminated algae than in control algae, this reduction was apparently not large enough to affect time to first brood in $D$. 
1 magna in our study (Table 2). This also suggests that the linolenic acid content of the $\mathrm{Cu}-$

2 exposed algae was most likely non-limiting. Finally, Park et al. (2002) derived an empirical

3 equation relating growth rate of D. magna to C:P ratio and total $\omega 3$-poly-unsaturated-fatty-

4 acid (PUFA) content of the food. Based on this equation and the data reported in Table 1, we

5 estimated growth rates of daphnids of $37 \%$ of body mass increase per day for both the control

6 and the dietary $\mathrm{Cu}$ treatment. These predicted growth rates are the same because in both

7 control and $\mathrm{Cu}$-contaminated food treatments neither the $\mathrm{C}: \mathrm{P}$ ratio nor the $\omega 3$-PUFA-content

8 were limiting (according to a comparison with limiting levels cited by Park et al., 2002).

9 Indeed, the C:P ratio of both food sources was below the limiting level of 300, indicating that enough phosphorous was available. Also, the $\omega 3$-PUFA-content of both food sources was

11 higher than the limiting level of $20 \mathrm{nmol} / \mathrm{g} \mathrm{C}$ (Table 1). Thus, the observed differences in fatty 12 acids and $\omega 3$ - PUFA between control and $\mathrm{Cu}$-exposed algae were not important enough to 13 affect growth rate of the daphnids. We can summarize that, taking into account current knowledge about diet quality for D. magna, it is not likely that the adverse effects observed in our study are due to $\mathrm{Cu}$-induced changes in nutritional quality of the food.

D. magna fed with algae pre-exposed to $500 \mu \mathrm{g} \mathrm{Cu} / \mathrm{L}$ and with a copper burden of $3,000 \mu \mathrm{g}$ $\mathrm{Cu} / \mathrm{g}$ dry wt (Table 1), clearly exhibited impaired growth and reproduction compared to daphnids fed with control algae with a copper burden of only $10.6 \mu \mathrm{g} \mathrm{Cu} / \mathrm{g}$ dry wt (Table 2). Chang and Sibley (1993) also demonstrated impaired reproduction upon feeding D. magna with $\mathrm{Cu}$-contaminated algae. However, these authors did not consider the above-mentioned confounding factors. This prohibits a straight-forward comparison with our data. Earlier, we reported a stimulation of daphnid growth and reproduction when D. magna were fed with the same algal species with lower internal copper burdens between 327 and 1,360 $\mu \mathrm{g} \mathrm{Cu} / \mathrm{g}$ dry wt 
1 exposed to a wide range of dietary $\mathrm{Cu}$ doses in a single experiment, is needed to investigate

2 whether responses of daphnids to dietary $\mathrm{Cu}$ exhibit a hormesis-like pattern.

4 The toxic response to dietary copper in D. magna is not the same as the one observed

5 following exposure to dietary Zn (De Schamphelaere et al., 2004). While dietary Zn

6 exclusively inhibited reproduction (De Schamphelaere et al., 2004), dietary Cu reduced

7 reproduction, growth and per capita algal ingestion rate (Table 2, Figure 1). This implies that

8 a broad spectrum of mechanisms and processes may be involved in the overall stress response

9 of D. magna to dietary $\mathrm{Cu}$ exposure.

10 According to the energy allocation theory, the inhibition of growth and reproduction may be

11 explained in terms of reduced energy acquisition and/or increased energy consumption (e.g.,

12 Kooijman, 2000; Nogueira et al., 2004). Increased metabolic costs to withstand toxicant stress

13 and inhibition of food assimilation can both result in a reduction of growth and reproduction.

14 Increased metabolic activity could for example be required for restoration of bio-molecules

15 that are damaged by redox-cycling induced by accumulated $\mathrm{Cu}$ (Mason and Jenkins, 1995) or

16 for detoxification processes such as metallothionein production (Amiard et al., 2006) or

17 copper storage in granules (Bryan and Gibbs, 1983). Bossuyt and coworkers also suggested

18 that increased energy expenditure for detoxification of accumulated $\mathrm{Cu}$ caused reduction in

19 energy reserves, growth and reproduction. They demonstrated that D. magna was able to

20 detoxify copper up to body burdens of around $100 \mu \mathrm{g} \mathrm{Cu} / \mathrm{g}$ dry wt without affecting energy

21 reserves, growth or reproduction (Bossuyt et al., 2005), while body burdens between 150 and

$22350 \mu \mathrm{g} \mathrm{Cu} / \mathrm{g}$ dry wt clearly reduced energy reserves, growth and reproduction (Bossuyt and

23 Janssen, 2005a). The internal body burden of $325 \mu \mathrm{g} \mathrm{Cu} / \mathrm{g}$ observed in the present study could

24 thus also explain the reduction of growth and reproduction. 
1 However, reduced energy reserves can also be the result of reduced energy acquisition (as

2 opposed to increased energy consumption), it is also possible that reduced energy acquisition

3 has contributed to the observed toxic effects in the present study. Toxicants can reduce energy

4 acquisition by inhibiting food ingestion, food assimilation efficiency, or a combination of

5 both (Allen et al., 1995; Kooijman, 2000). Exposure to dissolved copper has been

6 demonstrated to result in feeding inhibition in D. magna (Flickinger et al., 1982; Ferrando et

7 al., 1993), but it is not easy to discriminate between the relative importance of waterborne and

8 dietary exposure routes in these studies. Our study revealed that per capita ingestion rates of

9 D. magna exposed to dietary $\mathrm{Cu}$ were inhibited (Figure 1), meaning that an exposed

10 individual ingested significantly less food than a non-exposed individual. However, it is

11 known that per capita feeding rates of Daphnia are proportional to size (Evers and Kooijman,

12 1989; Porter et al., 1982; Kooijman, 2000) and not accounting for this factor can lead to

13 incorrect interpretations about toxicity mechanisms.

14 While at the end of the exposure (between day 19 to day 21) per capita ingestion rates in the

$15 \mathrm{Cu}$-exposed daphnids were $38 \%$ lower than in control daphnids (Table 2), the $\mathrm{Cu}$ exposed

16 daphnids also weighed 38\% less than control daphnids (Table 2). Assuming a daphnid's per

17 capita ingestion rate is proportional to its squared length, $l^{2}$ (Kooijman, 2000), and assuming

18 D. magna dry weight to be a power function of length with an average exponent of 2.4 (Porter

19 et al., 1982), we calculated that the size-corrected ingestion rates of $\mathrm{Cu}$-exposed and control

20 daphnids differed by only $7 \%$. Thus, it is likely that the inhibition of per capita ingestion rates

21 by dietary $\mathrm{Cu}$ does not reflect an inhibition of the physical process of ingestion (e.g., related

22 to toxicant-induced reduction of appendage beat rate as suggested by Allen et al., 1995), but

23 that this observation is merely a reflection of reduced growth. This view is supported by the

24 observation that the relative inhibition of per capita ingestion rates increased with time

25 (Figure 1), mainly because ingestion rates of the $\mathrm{Cu}$-exposed daphnids did not increase 
1 significantly between the $5^{\text {th }}$ and $21^{\text {st }}$ day of exposure. Such an increase would be expected in

2 normally growing and developing daphnids, as demonstrated by the observations of the

3 control daphnids (Figure 1).

4 Even if the physical process of ingestion itself is not affected, it is still possible that energy

5 acquisition is reduced through a decrease of assimilation efficiency. This could be the result

6 of inhibition of digestive enzyme activity in the gut. Indeed, following Allen et al. (1995) this

7 is the likely cause of inhibition of energy acquisition in D. magna for a range of contaminants

8 associated with algal cells, including the metal Cd. Chen et al. (2002) demonstrated that high

$9 \mathrm{Cu}$ concentrations inhibited digestive enzyme activity in the digestive fluids of several benthic

10 invertebrates. It is thus possible that a reduction of digestive enzyme activity is involved in

11 the inhibition of growth and reproduction in D. magna exposed to elevated levels of dietary

$12 \mathrm{Cu}$. Supported by the fact that Chen et al. (2002) found a stimulation of digestive enzyme activity at low copper levels, we also considered this mechanism to be the most plausible for explaining enhanced growth and reproduction of D. magna at dietary copper levels lower than 15 the one investigated in the present study (De Schamphelaere et al., 2004).

Although it is tempting to relate growth and reproductive responses of $D$. magna at different dietary copper concentrations to digestive processes and effects on assimilation efficiency, the absence of data on growth and energy consumption throughout the exposure period makes it impossible to rule out the explanation of increased metabolic costs to cope with copper stress.

21 Furthermore, although both mechanisms can partially explain most observations, they do not necessarily explain all observations. This follows from the fact that time to first brood (about 12 days) was not significantly affected by dietary $\mathrm{Cu}$, while the size of this brood was significantly reduced by $35 \%$ (Table 2). Different authors have indicated that increased metabolic cost or reduced food assimilation would both result in a slower maturation and, 
1 hence, a delayed onset of reproduction in D. magna (Kooijman, 2000; Nogueira et al., 2004).

2 Therefore, it is rather unlikely that energy acquisition and/or consumption were adversely

3 affected by dietary $\mathrm{Cu}$ before the $12^{\text {th }}$ day of exposure and it is rather likely that another

4 toxicity mechanism is needed to explain the reduction of the first brood size.

6 Several studies have suggested that the mechanisms of reproductive toxicity of dietborne

7 metals to marine copepods ( $\mathrm{Hg}, \mathrm{Ag}, \mathrm{Cd}, \mathrm{Zn}, \mathrm{Mn})$, blue crabs $(\mathrm{Cd})$, freshwater cladocerans

8 (Ag), and D. magna ( $\mathrm{Zn})$ may be related to the inhibition of processes involved in

9 vitellogenesis (Hook and Fisher, 2001a, 2001b, 2002; Lee and Noone, 1995; De

10 Schamphelaere et al., 2004). This mechanism may not only explain the reduction of the first

11 brood size, but also of the sizes of the second and the third broods in Cu-exposed D. magna.

12

Interestingly, the third brood size of $\mathrm{Cu}$-exposed daphnids is more reduced (i.e., by 55\%) than the first and second broods (i.e., by 35\%) (Table 2). This could be due to an increase of the targeted effect on vitellogenesis with time. The increase of reproductive toxicity with time was also observed following dietary Zn exposure of D. magna (De Schamphelaere et al., 2004). Another possible explanation is that adverse effects on energy acquisition and/or consumption, as discussed above, were initiated during instar A3, i.e. the instar between the release of the first and second brood and also the instar during which the third brood is provisioned, i.e. between day 12 and day 15 of the exposure (we use the instar nomenclature of Nogueira et al., 2004). The hypothesis of the initiation of effects on energy acquisition after day 12 may be supported by the increased instar duration of the instars A3 and A4 (Table 2). Indeed, Nogueira et al. (2004) demonstrated that food deprivation during an instar of $D$. magna resulted in an increased duration of this instar. Although this makes the energy acquisition hypothesis again very attractive, it is not definite because it is, to our knowledge, 
1 currently unknown whether or not increased metabolic costs imposed by toxicant stress can

2 also affect instar duration in D. magna. It can also not be ruled out that dietary copper

3 affected instar duration directly by interfering with the ecdysteroid metabolism, which

4 regulates the moult cycle, such as observed in D. magna exposed to Cd (Bodar et al., 1990).

5 Since reduced energy acquisition and/or increased energy consumption are required to explain

6 the reduced size of the $\mathrm{Cu}$-exposed daphnids at the end of the experiment (Table 2), at least

7 one of these mechanisms most likely also contributed at least partially to the aggravated effect

8 on the third brood size. The current dataset does, however, not allow us to explain why energy

9 acquisition and/or consumption are most probably only affected after 12 days of exposure to

10 dietary copper, i.e. after instar A2, and not before this time.

Although our finding that dietary $\mathrm{Cu}$ can cause toxic effects on D. magna is important from a mechanistic point of view, it must be acknowledged that the $\mathrm{Cu}$ concentration to which the algal food was exposed, i.e. $494 \mu \mathrm{g} / \mathrm{L}$, as well as the internal $\mathrm{Cu}$ concentration in the algal food that was needed to invoke toxicity in D. magna, i.e. 3,000 $\mu \mathrm{g} \mathrm{Cu} / \mathrm{g}$ dry wt, will not often

16 be found in natural environments. Also, D. magna reproduction has been shown to be inhibited by $50 \%$ at a three-fold lower waterborne concentration, i.e. $167 \mu \mathrm{g} \mathrm{Cu} / \mathrm{L}$ (see above). One may therefore suggest that, even under such extremely polluted conditions, copper toxicity will be primarily caused by waterborne exposure and less by the dietary component. Additionally, given the 59\% reduced growth rate of the algae (Table 1) at internal copper burdens causing dietary toxicity to D. magna, it could be argued that algal food may disappear from natural systems at $\mathrm{Cu}$ concentrations lower than those that could lead to dietary toxicity. For all these reasons, one could argue that dietborne $\mathrm{Cu}$ toxicity to crustaceans is of limited concern in freshwater systems. However, it must be kept in mind that the above reasoning is only valid for the presently investigated simple system of a single 
1 crustacean species (D. magna) grazing on a single species of algal food (P. subcapitata). It is

2 for instance well-known that there are considerable inter-species differences in

3 bioconcentration factors of copper in green algae (up to factor 10; Yan and Pan, 2002) as well

4 as in he amount of internalized copper at which algae are still able to thrive in natural systems

5 (more than two orders of magnitude; De Schamphelaere et al., 2005). Thus, the dietary Cu

6 dose at a given waterborne concentration in a natural system may be highly dependent on the

7 local algal species community as well as on the food preference of local crustaceans. Also,

8 because there is considerable inter-species differences of waterborne copper toxicity among

9 crustaceans (Brix et al., 2001; Bossuyt and Janssen, 2005b), it is possible that sensitivity to

10 dietary copper also exhibits an important among-species variation in crustaceans. Finally,

11 waterborne and dietary sensitivities do not necessarily correlate and, hence, the relative

12 importance of dietary and waterborne $\mathrm{Cu}$ exposure routes to toxicity may also vary among

13 species. Thus, although it is acknowledged that the current study does not necessarily

14 represent a naturally realistic scenario, the fact alone that dietary $\mathrm{Cu}$ exerts toxicity on a

15 model crustacean warrants further research into the inter-species variability of sensitivity to

16 dietary copper, including research about the importance of the algal species used a food

17 source.

19 Conclusions and research perspectives

20 D. magna fed for 21 days with algal food ( $P$. subcapitata) contaminated with $3,000 \mu \mathrm{g} \mathrm{Cu} / \mathrm{g}$

21 dry wt accumulated a total copper body burden of $325 \mu \mathrm{g} \mathrm{Cu} / \mathrm{g}$ dry wt and clearly experienced

22 inhibited growth and reproduction. We have demonstrated that these toxic effects were most

23 likely not the result of elevated dissolved copper concentrations in the exposure solutions

24 (waterborne exposure) or of a reduced nutritional quality of the algal food. Analysis of life-

25 history and other biological traits such as algal ingestion rate, growth, time-to-first brood, 
1 instar duration and brood size suggest the possible involvement of several toxicity

2 mechanisms such as increased energy consumption, reduced energy acquisition (potentially

3 via inhibition of digestive enzyme activity), targeted inhibition of reproduction (potentially

4 via inhibition of vitellogenesis), or even direct effects on moulting. The data also seem to

5 suggest that direct inhibition of reproduction occurs from the first brood, but that all other

6 effects are most probably initiated after the release of the first brood $\left(12^{\text {th }}\right.$ day of exposure). A

7 distinct explanation for this observation is lacking. Clearly more research is needed to

8 differentiate between these postulated mechanisms of dietary $\mathrm{Cu}$ toxicity, to determine which

9 mechanisms act separately or in concert on each biological trait, and to determine how these

10 mechanisms vary during a chronic exposure or with the age of a daphnid.

12 Acknowledgement

13

14 Karel De Schamphelaere is supported by a post-doctoral fellowship from the Flemish

15 scientific research fund (FWO-Vlaanderen, Belgium). Additional funding was obtained from

16 the Ghent University Research Funds (BOF-01110501 and BOF-01J09506. We thank Emmy

17 Pequeur, Jill Van Reybrouck, Leen Van Imp, Gisèle Bockstael, Marc Vanderborght, Guido

18 Uyttersprot and Geert Van De Wiele for technical assistance. We also wish to thank two

19 anonymous reviewers, who aided in the improvement of an earlier version of the manuscript. 


\section{References}

2 Allen, Y., Calow, P., Baird, D.J., 1995. A mechanistic model of contaminant-induced feeding inhibition in Daphnia magna. Environ. Toxicol. Chem. 14,1625-1630.

4

Amiard, J.C., Amiard-Triquet, C., Barka, S., Pellerin, J., Rainbow, P. S., 2006.

Metallothioneins in aquatic invertebrates: Their role in metal detoxification and their use as biomarkers. Aquat. Toxicol. 76,160-202.

Becker, C., Boersma, M., 2005. Differential effects of phosphorus and fatty acids on Daphnia magna growth and reproduction. Limnol. Oceanogr. 50, 388-397.

Bodar, C.W.M., Voogt, P.A., Zandee, D.I., 1990. Ecdysteroids in Daphnia magna: their role in moulting and their levels upon exposure to cadmium. Aquat. Toxicol. 17, 339-350.

Borgmann, U., Janssen, C.R., Blust, R.J.P., Brix, K.V., Dwyer, R.L., Erickson, R.J., Hare, L., Luoma, S.N., Paquin, P.R., Roberts, C.A., Wang, W., 2005. Incorporation of Dietborne metals exposure into regulatory frameworks. In: Meyer, J.S., Adams, W.J., Brix; K.V.,

Luoma, S.N., Mount, D.R., Stubblefield, W.A., Wood, C.M. (Eds.), Toxicity of dietborne metals to aquatic organisms, SETAC, Pensacola, Fl, USA, pp. 153-189.

Bossuyt B.T.A., Janssen C.R., 2005a. Copper regulation and homeostasis of Daphnia magna and Pseudokirchneriella subcapitata: influence of acclimation. Environ. Pollution 136, 135144.

Bossuyt, B.T.A., Janssen, C.R., 2005b. Copper toxicity to different field-collected cladoceran species: Intra- and inter species sensitivity. Environ Pollut 136, 145-154.

Bossuyt B.T.A., Janssen C.R., Escobar Y.R., 2005. Multigeneration acclimation of Daphnia $327-336$. 
1 Brix, K.V., Deforest, D.K., Adams, W.J., 2001. Assessing acute and chronic copper risks to

2 freshwater aquatic life using species sensitivity distributions for different taxonomic groups.

3 Environ. Toxicol. Chem. 20, 1846-1856.

4

5 Bryan, G.W., Gibbs, P.E., 1983. Heavy metals in the Fal estuary, Cornwall: a study of long-

6 term contamination by mining waste and its effects on estuarine organisms. Marine Biology

7 Association UK Ocassional Publication 2, 1-112.

9 Chang, C., Sibley, T.H., 1993. Accumulation and transfer of copper by Oocystis pusilla. Bull. Environ. Contam. Toxicol. 50, 689-695.

11

Chen, Z., Mayer, L.M., Weston, D.P., Bock, M.J., Jumars, P.A. 2002. Inhibition of digestive enzyme activities by copper in the guts of various marine benthic invertebrates. Environ.

Toxicol. Chem. 25,32-36.

Clearwater, S.J., Farag, A.M., Meyer, J.S., 2002. Bioavailability and toxicity of dietary copper and zinc to fish. Comp. Biochem. Physiol. 132C, 269-313.

Clesceri, L.S., Greenberg, A.E., Eaton, A.D., 1998. Standard Methods for the Examination of

Water and Wastewater, $20^{\text {th }}$ Edition, American Public Health Association, Washington, DC, USA.

De Schamphelaere, K.A.C., Canli, M., Van Lierde, V., Forrez, I., Vanhaecke, F., Janssen, C.R., 2004. Reproductive toxicity of dietary zinc to Daphnia magna. Aquat. Toxicol. 70, 233-244.

De Schamphelaere, K.A.C., Janssen, C.R., 2004a. Effects of chronic dietary copper exposure on growth and reproduction of Daphnia magna. Environ. Toxicol. Chem. 23, 2038-2049. concentration and source, $\mathrm{pH}$ and water hardness on chronic toxicity of copper to Daphnia magna. Environ. Toxicol. Chem. 23, 1115-1122. 
1 De Schamphelaere, K.A.C., Stauber, J.L., Wilde, K.L., Markich, S.J., Brown, P.L., Franklin,

2 N.M., Creighton, N.M., Janssen, C.R., 2005. Toward a biotic ligand model for freshwater

3 green algae: surface-bound and internal copper are better predictors of toxicity than free $\mathrm{Cu}^{2+}$

4 ion activity when pH is varied. Environ. Sci. Technol. 39, 2067-2072.

6 De Schamphelaere, K.A.C., Vasconcelos, F.M., Heijerick, D.G., Tack, F.M.G., Delbeke, K., 7 Allen, H.E., Janssen, C.R., 2003. Development and field validation of a predictive copper 8 toxicity model for the green alga Pseudokirchneriella subcapitata. Environ. Toxicol. Chem., $922,2454-2465$.

Elendt, B.P., Bias, W.R., 1990. Trace nutrient deficiency in daphnia magna cultured in standard medium for toxicity testing, effects of the optimization of culture conditions on life history parameters of D. magna. Water Res. 24,1157-1167.

Evers, E.G., Kooijman, SALM. 1989. Feeding, digestion and oxygen consumption in Daphnia magna: a study in energy budgets Netherlands Journal of Zoology 39, 56-78.

Ferrando, M.D., Andreu, E., 1993. Feeding behaviour as an index of copper stress in Daphnia magna and Brachionus calyciflorus. Comp. Biochem. Phsyiol.106C, 327-331

Flickinger, A.L., Bruins, R.J.F., Winner, R.W., Skilling, J.H., 1982. Filtration and phototactic behavior as indices of chronic copper stress in Daphnia magna Straus. Arch. Environ. Contam. Toxicol. 11, 457-463

Gevaert, L., 2004. Gevoeligheid van diverse cladocerensoorten voor koper (Sensitivity of different cladoceran species to copper). M. Sc. thesis, Faculty of Bioscience Engineering, University of Gent, Belgium, 95 pages (in Dutch).

Gillis, P.L., Chow-Frasera, P., Ranville, J.F., Ross, P.E., Wood, C.M., 2005. Daphnia need to be gut-cleared too: the effect of exposure to and ingestion of metal-contaminated sediment on the gut-clearance patterns of D. magna. Aquat. Toxicol. 71, 143-154. 
2 Hook, S.E., Fisher, N.S., 2001b. Sublethal effects of silver in zooplankton: importance of

3 exposure pathways and implications for toxicity testing. Environ. Toxicol. Chem. 20, 568-

4574.

Hook, S.E., Fisher, N.S., 2002. Relating the reproductive toxicity of five ingested metals in calanoid copepods with sulfur affinity. Marine Environ. Res. 53, 161-174.

9 Kicrhgessner, M., Beyer, M.G., Steinhart, H., 1976. Activation of pepsin (EC3.4.4.1.) by heavy metal ions including a contribution to mode of action of copper-sulfate in pig nutrition. Brit. J. Nutr. 36,15-22.

Kooijman, S.A.L.M., 2000. Dynamic energy and mass budgets in biological systems, $2^{\text {nd }}$ edition. Cambridge University Press, Cambridge, United Kingdom.

Lee, R.F., Noone, T., 1995. Effect of reproductive toxicants on lipovitellin in female blue crabs, Callinectes sapidus. Marine Environ. Res. 39, 151-154.

Lepage, G., Roy, C.C., 1984. Improved recovery of fatty acid through direct

Mason, A.Z., Jenkins, K.D., 1995. Metal Detoxification in Aquatic Organisms. In: Tessier, A., Turner, D.R. (Eds.), Metal Speciation and Bioavailability in Aquatic Systems, John Wiley \& Sons, New York, NY, USA, pp. 479-608.

McLarnon-Riches, C.J., Rolph, C.E., Greenway, D.L.A., Robinson, P.K.. 1998. Effects of environmental factors and metals on Selenastrum capricornutum lipids. Phytochem. 49, 12411247.

Meyer, J.S., Adams, W.J., Brix; K.V., Luoma, S.N., Mount, D.R., Stubblefield, W.A., Wood, 
1 Moreno-Garrido, I., Lubian, L.M., Soares, A.M.V.M., 1999. In vitro populations of rotifer

2 Brachionus plicatilis Muller demonstrate inhibition when fed with copper-preaccumulating 3 microalgae. Ecotoxicol. Environ. Safety 44, 220-225.

4

5 Nogueira, A.J.A., Baird, D.J., Soares, A.M.V.M., 2004.Testing physiologically-based

6 resource allocation rules in laboratory experiments with Daphnia magna Straus. Int. J.

7 Limnol. 40, 257-267.

8

9 OECD, 1984. Test Guideline No. 201: Alga growth inhibition test. Organization for Economic Cooperation and Development, Paris, France.

OECD, 1998. Test Guideline No. 211: Daphnia magna reproduction test. Organization for

Economic Cooperation and Development, Paris, France.

Park, S., Brett, M.T., Muller-Navarra, D.C., Goldman, C.R., 2002. Essential fatty acid content and the phosphorus to carbon ratio in cultured algae as indicators of food quality for Daphnia. Freshwater Biol. 47, 1377-1390.

Porter, K.G., Gerritsen, J., Orcutt, J.D., 1982. The effect of food concentration on swimming patterns, feeding behavior, ingestion, assimilation, and respiration by Daphnia. Limnol. Oceanogr. 27, 935-949.

Schlekat, C.E., Lee, B., Luoma, S.N., 2001. Dietary metals exposure and toxicity to aquatic organisms: implications for ecological risk assessment. In: Newman, M.C., Roberts, M.H., Hale, R.C. (Eds.), Coastal and estuarine risk assessment, Lewis Publishers, Boca Ration, USA, Fl, pp. 151-187.

Sundbom, M., Vrede, T., 1997. Effects of fatty acid and phosphorus content of food on the growth, survival and reproduction of Daphnia. Freshwater Biol. 38, 665-674. Von Elert, E., 2002. Determination of limiting polyunsaturated fatty acids in Daphnia galeata using a new method to enrich food algae with single fatty acids, Limnol. Oceanogr. 47,17641773. 
1 Yan, H., Pan, G. 2002. Toxicity and bioaccumulation of copper in three green microalgal 2 species. Chemosphere 49, 471-476.

3

4 Wikfors, G.H., Ukeles, R., 1982. Growth and adaptation of estuarine unicellular algae in 5 media with excess copper, cadmium or zinc, and effects of metal-contaminated algal food on 6 Crassostrea virginica larvae. Marine Ecol. Progr. Ser. 7, 191-206. 


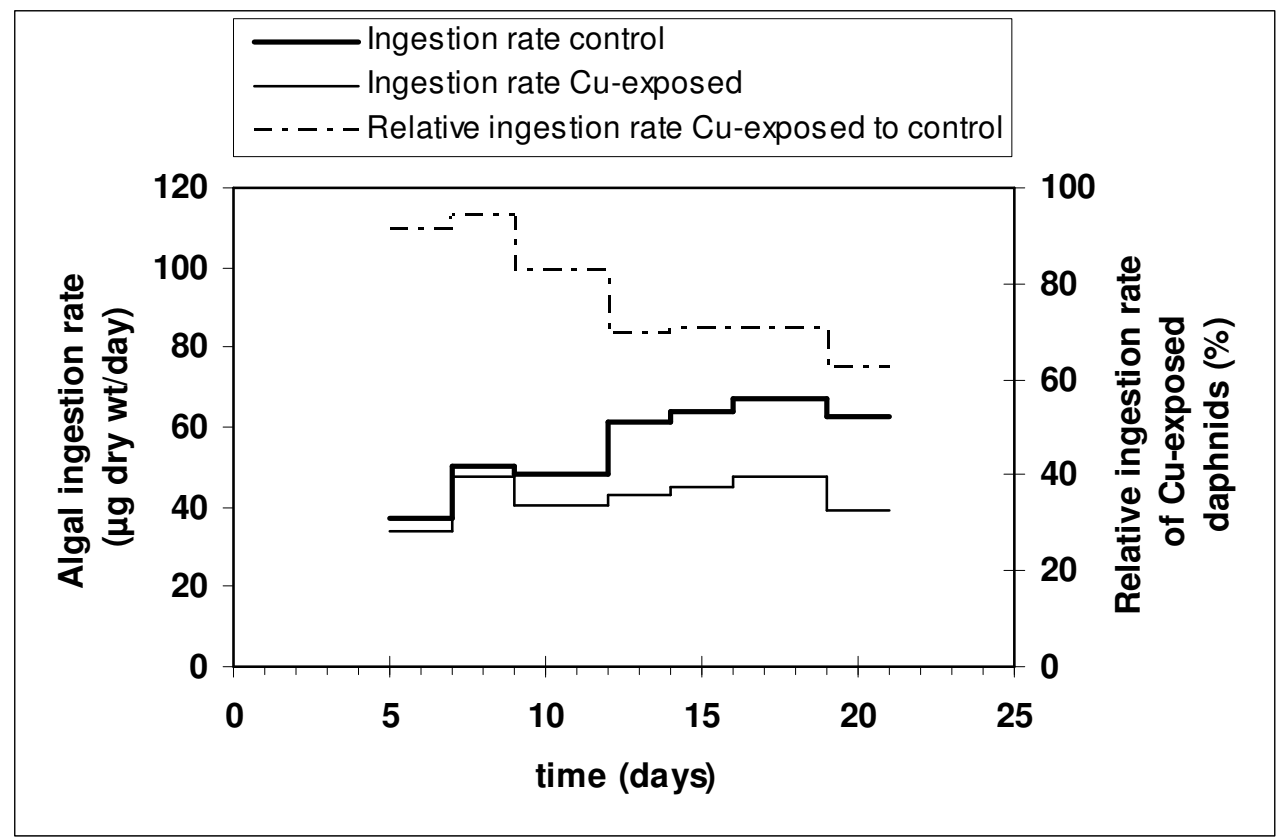

Figure 1 Algal ingestion rate (left axis) of Daphnia magna fed with control and $\mathrm{Cu}-$ contaminated algae and relative ingestion rates of $\mathrm{Cu}$-exposed daphnids compared to control daphnids (right axis). 
Table 1 Characteristics of algae cultured in control medium (no added $\mathrm{Cu}$ ) and in medium containing $500 \mu \mathrm{g} \mathrm{Cu} / \mathrm{L}$.

\begin{tabular}{|c|c|c|}
\hline & Control treatment & $500 \mu \mathrm{g} \mathrm{Cu} / \mathrm{L}$ treatment \\
\hline $\begin{array}{l}\text { Disolved } \mathrm{Cu} \text { during algal exposure } \\
( \pm \text { stdev }, \mathrm{n}=4)\end{array}$ & $1.9 \pm 0.3(2.3-1.7)^{\mathrm{a}}$ & $494 \pm 42(535-437)^{\mathrm{a}}$ \\
\hline Biomass growth rate $\left(\mathrm{d}^{-1}\right)$ & 0.881 & 0.364 \\
\hline Internal $\mathrm{Cu}(\mu \mathrm{g} / \mathrm{g}$ dry wt $)( \pm$ stdev, $\mathrm{n}$ & & \multirow[b]{2}{*}{$2,720 \pm 160$} \\
\hline Day 0 & $12.3 \pm 2.9$ & \\
\hline Day 21 & $8.9 \pm 0.2$ & $3,290 \pm 80$ \\
\hline Mean of day 0 and day 21 & 10.6 & 3,000 \\
\hline External $\mathrm{Cu}(\mu \mathrm{g} / \mathrm{g}$ dry $w \mathrm{t})( \pm$ stdev, & & \\
\hline Day 0 & $<1.2$ & $3,053 \pm 6$ \\
\hline Day 21 & $<1.2$ & $4,055 \pm 10$ \\
\hline Mean of day 0 and day 21 & $<1.2$ & 3,554 \\
\hline Molar C:P ratio & 274 & 241 \\
\hline Fatty acids ${ }^{c}$ & $\mathrm{mg} / \mathrm{g}$ dry wt & mg/g dry wt \\
\hline Palmitic acid, 16:0 & 145.5 & 182.5 \\
\hline Oleic acid, 18:1(n-9) & 170.1 & 452.7 \\
\hline Linoleic acid, 18:2(n-6) & 43.7 & 21.3 \\
\hline Linolenic acid*, 18:3(n-3) & 94.9 & 59.7 \\
\hline Stearidonic acid*, 18:4(n-3) & 26.1 & 25.3 \\
\hline $\mathrm{EPA}^{*}, 20: 5(\mathrm{n}-3)^{\mathrm{d}}$ & 0.57 & 4.52 \\
\hline $\mathrm{DHA}^{*}, 22: 6(\mathrm{n}-3)^{\mathrm{e}}$ & $<0.02$ & $<0.02$ \\
\hline Total $\omega 3$-PUFA content ${ }^{\mathrm{f}}$ & $14.0^{\mathrm{c}}$ & 10.0 \\
\hline Total fatty acid content & 65.7 & 93.5 \\
\hline
\end{tabular}

${ }^{\text {a }}$ Figures between parentheses are the initial and final concentration, respectively

${ }^{\mathrm{b}}$ External copper is operationally defined as the copper that is desorbed from the algal surface by a 20 minute wash in a solution of a $5 \mathrm{mM}$ ethylene-diamine-tetra-acetic acid solution.

Internal copper is the copper remaining inside the cells after this treatment (De

Schamphelaere and Janssen, 2004a; see also Materials and Methods).

${ }^{c}$ Fatty acid nomenclature reported after comma, concentrations given in two different units in columns 2-5 (nmol/g C and $\mathrm{mg} / \mathrm{g}$ dry wt)

${ }^{\mathrm{d}} \mathrm{EPA}=$ eicosapentaenoic acid

${ }^{\mathrm{e}} \mathrm{DHA}=$ docosahexaenoic acid

${ }^{\mathrm{f}} \omega 3$-PUFA $=$ omega-3 poly-unsaturated fatty acids; they are marked with a $*$ next to their name in the first column 
Table 2 Results of the chronic bioassays with Daphnia magna fed with control algae and algae pre-exposed to $500 \mu \mathrm{g} \mathrm{Cu} / \mathrm{L}$ (nominal). Data are reported as mean \pm standard deviation where applicable. Significant differences between daphnids fed $\mathrm{Cu}$-contaminated and control food are indicated by $* \mathrm{p}<0.05, * * \mathrm{p}<0.01, * * * \mathrm{p}<0.001 ; \mathrm{NS}=$ not significant (Mann Whitney U test).

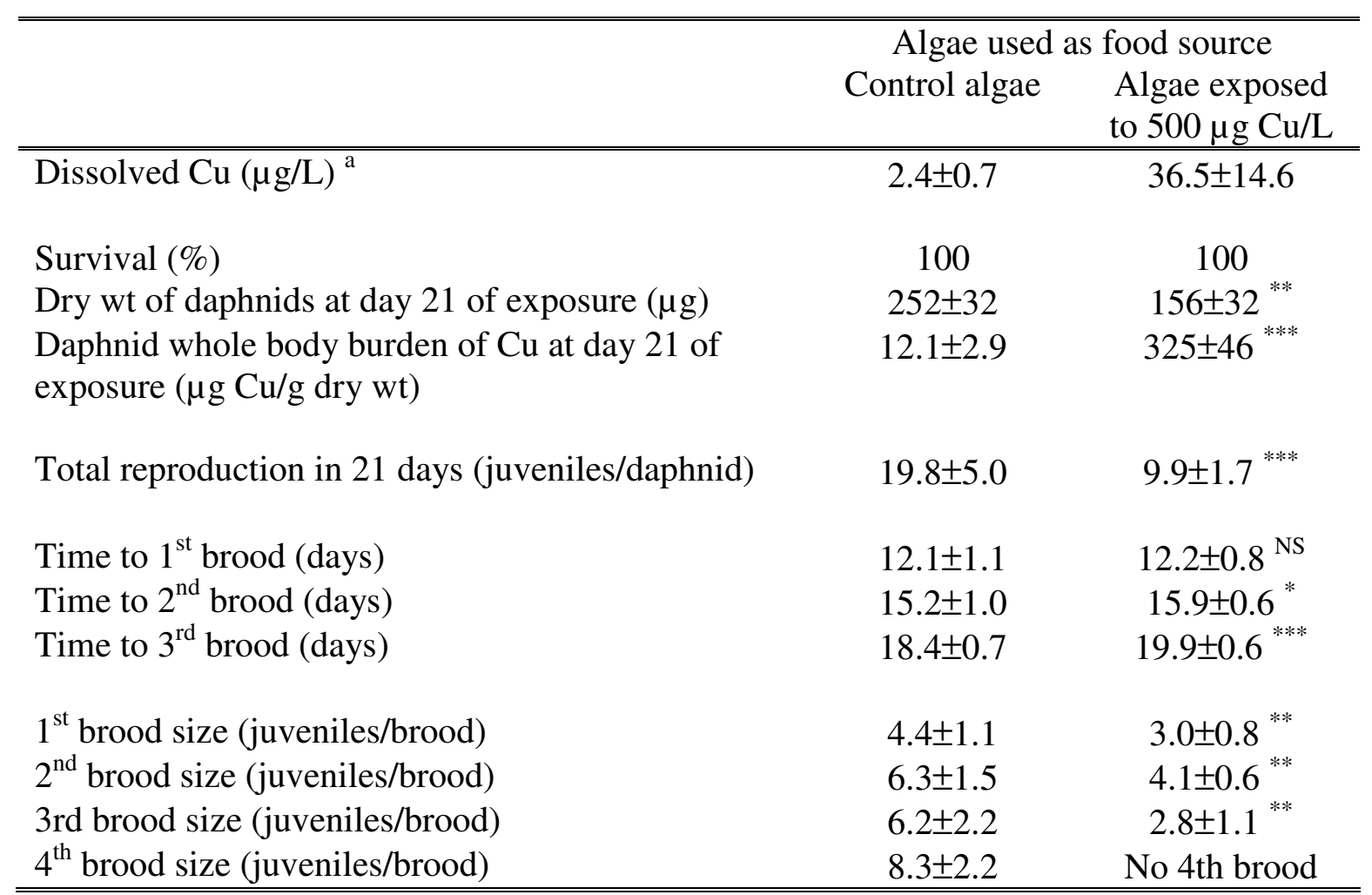

\footnotetext{
${ }^{\mathrm{a}}$ Measured in old test solutions ( $\mathrm{n}=9$ ); concentration in fresh solution was $2.3 \mu \mathrm{g} \mathrm{Cu} / \mathrm{L}$ in both treatments
} 